\title{
Hemostatic Effects of Oral Contraceptives in Women who Developed Deep-vein Thrombosis while Using Oral Contraceptives
}

\author{
Kitty W. M. Bloemenkamp, Frits R. Rosendaal, Frans M. Helmerhorst, Ted Koster, \\ Rogier M. Bertina, Jan P. Vandenbroucke
}

From the Department of Obstetrics, Gynaecology and Reproductive Medicine (K. W. M. Bloemenkamp, F. M. Helmerhorst), Department of Clinical Epidemiology (T. Koster, F. R. Rosendaal, J. P. Vandenbroucke), Thrombosis and Hemostasis Research Center (F. R. Rosendaal, R. M. Bertina), University Hospital Leiden, Leiden,

The Netherlands

\section{Summary}

Objective: Comparison of the effect of oral contraceptives on hemostatic variables in venous thrombosis patients (thrombosis while using oral contraceptives) with the effect in healthy control subjects. Our aim was to assess whether some of these effects were more pronounced in women who had suffered thrombosis, i.e., whether these were "hemostatic hyperresponders". Study Design: A population-based case-control study, the Leiden Thrombophilia Study. Materials and Methods: We investigated 99 pre-menopausal women, age 15-49 years, who had used oral contraceptives at the time of a first, objectively confirmed episode of deep-vein thrombosis. They were not pregnant, nor in puerperium, nor had had a recent miscarriage, and were not using injectable progestogens, nor suffering from inherited coagulation defects. The median time between occurrence of deep-vein thrombosis and venepuncture was 18 months, and 30 of the 99 women were still using oral contraceptives, while 69 had discontinued oral contraceptive use. In addition, a group of 153 control women ( 54 of them were oral contraceptive users and 99 were non-users) were studied. The following hemostatic variables were measured: APTT, factor VII, factor VIII, factor XII, fibrinogen, prothrombin, total antithrombin, normalised activated protein $C$ sensitivity ratio ( $n$-APC-sr), protein $C$, protein $S$ and free protein S. Results: We found marked and significant effects of oral contraceptive use on the levels of several clotting factors, with an increase in factor VII, factor XII, protein C and a decrease in antithrombin, n-APC-sr and protein $S$. Less marked effects that were non-significant or only significant in either patients or controls, were an increase in factor VIII, fibrinogen and prothrombin and a decrease in the APTT and free protein S. In the former thrombosis patients several of these effects of oral contraceptives were more pronounced than in healthy women: specifically on factor VII, antithrombin, n-APC-sr and protein C. Conclusions: Our results of the effects of oral contraceptives generally confirm previous reports in healthy volunteers. Our data also show that in former deep-vein thrombosis patients these effects are more pronounced. Apparently some women become "high hemostatic responders" when exposed to oral contraceptives, and they may be the women most vulnerable to its thrombogenic effects.

Correspondence to: Dr. F. R. Rosendaal, Department of Clinical Epidemiology, Leiden University Hospital, Bldg 1-CO-P, P.O. Box 9600, 2300 RC Leiden, The Netherlands - Tel.: +31 71 5264037; FAX Number: +31 71 5248122

\section{Introduction}

Since the report of Jordan in 1961 (1) on the association of oral contraceptive use and venous thromboembolism, it has become generally accepted that there is an estrogen dose-dependent association between oral contraceptive use and venous thrombosis (2-5). Recently several studies have shown that the type of progestogen also plays a role in the development of venous thrombosis during oral contraceptive use (6-10). This resulted in renewed interest in the biological mechanisms underlying venous thrombosis during oral contraceptive use.

The natural balance between the pro-coagulant, anti-coagulant and fibrinolytic system may be disturbed by environmental factors, such as oral contraceptive use, or by hereditary defects in pro-coagulation, anticoagulation or fibrinolysis (11-12).

Previous studies have documented that oral contraceptives may stimulate pro-coagulation, inhibit anti-coagulation and stimulate fibrinolysis (13-16). Most studies on the hemostatic and fibrinolytic effects of oral contraceptives have been conducted in healthy volunteers. All these studies showed changes in hemostatic variables, mostly within physiological ranges and not all in the same, i.e. prothrombotic or antithrombotic, direction (13-16). It is still unclear if and how these hemostatic changes would result in an increased risk of venous thrombosis (17-19). From the recent clinical studies (6-10) it appears that these studies on intermediate end-points (plasma levels of hemostatic variables) have been of limited value in predicting clinical thrombosis risk.

Recently we described a gene-environment interaction between the factor V Leiden mutation (20) and oral contraceptive use. The factor $V$ Leiden mutation, which leads to resistance to activated protein C (APC) is commonly found among patients with venous thrombosis (21). In women who are not using oral contraceptives, this mutation increases the risk of thrombosis 7-fold (22), while the combination of use of oral contraceptives and carriership of the factor $V$ Leiden mutation increases the risk 30 - to 50 -fold $(9,22)$. For the other less frequent inherited clotting defects, i.e., protein C-, protein S- and antithrombin deficiency, oral contraceptive use may also act synergistically on the risk of development of venous thrombosis (23-27), though large data on these rare inherited clotting defects are lacking.

To explain why some women using oral contraceptives develop venous thrombosis and others not, interactions with other coagulation risk factors may also play a role. We postulated that some women are more prone to oral contraceptive-induced hemostatic changes and thus to thrombotic disease.

The ideal design to study this question would be to randomise women with a previous thrombosis during oral contraceptive use, to either 
use of oral contraceptives or placebo This offers obvious practical problems, and therefore we used a pseudo-randomized approach we analysed hemostatic variables in the Leiden Thrombophilia Study (LETS) (28) a population-based case-control study on risk factors for venous thrombosis In this study patients were invited for a visit at the outpatient clinic at least six months after the thrombotic event At that time, about one third of the women who had used oral contraceptıves at the time of the deep-vein thrombosis were still using oral contraceptives, two thirds had discontinued Since the decision to continue or discontinue oral contraceptives will depend to a great extend on the opinion of the physician, or on the feasibility of other contraception methods, and not on the hemostatic balance, this may be considered a "random" process, $1 \mathrm{e}$, pseudo-randomised In this way we assessed the effect of oral contraceptives in former thrombosis patients who developed venous thrombosis durnng oral contraceptive use, and contrasted this to the effect on hemostasis of oral contraceptives in healthy control women

\section{Materials and Methods}

\section{Patients and Control Subjects}

The patients and methods of our study have been described previously ( 22 , 28) We invited 474 consecutive patients ( 272 women) with a first episode of objectively demonstrated deep vein thrombosis (diagnosed by ultrasound, im pedance plethysmography or phlebography) occurrng between Jan 1, 1988 and Dec 31,1992 , aged less than 70 years and without a known malıgnant disorder Patients had been selected from the files of three anticoagulation clinics in the Netherlands, which montor anticoagulant treatment in all patients within a well defined geographical area For each thrombosis patient we invited one age- and sex-matched healthy control individual

Patients were seen after anticoagulant treatment had been discontinued for at least 3 months [median tıme elapsed since the thrombotic event 18 months (range 648 )], unless treatment could not be discontunued

For the present analysis we selected from the original study (28), premeno pausal women, aged 15-49 years, who were at the tume of therr thrombosis (or similar date in the control women, the index date) not pregnant, nor in the puer perium, did not have a recent miscarriage, and were not using progestogen only methods Women receiving anticoagulant treatment on the day of blood collection were excluded $(n=6)$ Also women with a protein $C-(n=6$, three of them also used anticoagulant treatment), protein $S-(n=9)$, antithrombin $(n=2)$ deficiency or the factor $V$ Leiden mutation $(n=41)$ were excluded when analysing the plasma levels of respectively protein C activity (29), total protein $S$ antigen and free protein $S$ antigen (29), antıthrombin activity (29) and normalised activated protein C sensitivity ratio ( $\mathrm{n}$-APC-sr) (28) The criteria for diagnosis of these abnormalities have been described before (29)

149 former thrombosis patients and 169 control women were included in our analysis (mean age 35 years) We divided this group in subgroups according to their oral contraceptive use in the month before the date of thrombosis and their oral contraceptive use on day of blood collection 21 women of whom no data were avalable on the use of oral contraceptives on the day of blood collection were excluded This resulted in the following subgroups (see Figure 1) women who developed deep-vein thrombosis during oral contraceptive use and were still using oral contraceptives at blood collection (group $A, n=30$ ), women who developed deep-vein thrombosis durıng oral contraceptive use and did not use oral contraceptives durng blood collection (group $B, n=69$ ), healthy control women using oral contraceptives during blood collection (group $\mathrm{C}, \mathrm{n}=54$ ) and healthy control women not using oral contraceptives durng blood collection (group D, $n=99$ ) Women who did not use oral contraceptives at the time of the thrombosis are not included in this analysis $(n=45)$

Blood collection Blood was collected from the antecubital vein into Sar stedt Monovette ${ }^{\circledR}$ tubes, containıng $0106 \mathrm{mmol} / 1$ trisodium citrate and centr1fuged for $10 \mathrm{~min}$ at $2000 \mathrm{~g}$ at room temperature The plasma was stored at $-70^{\circ} \mathrm{C}$ High-molecular-weight DNA was ssolated from leucocytes and stored at $4^{\circ} \mathrm{C}$
Laboratory measurements The following hemostatic variables were measured as previous described of the pro-coagulation system, activated partial thromboplastın tıme (APTT) (29), factor VII actıvity (30), factor VIII actıvity (31), factor XII activity (32), fibrinogen (30), prothrombin actıvity (29) and of the ant1-coagulatron system, antithrombin activity (29), normalised activated protem C sensitıvity ratıo (n APC sr) (28), proten C activity (29), total protein $S$ antigen and free protein $S$ antigen (29) Total protein $S$ was measured by polyclonal ELISA and free protein $S$ was measured directly in plasma by ELISA using two monoclonal antibodies specific for free protem $S$ (Asserachrom free protein S, Stago Diagnostıca, Asmeres-sur-Seıne, France) Results of the Activated Protein $C$ resistance test are expressed as normalised APC sensi tivity ratios (n-APC-sr) (33) Detection of the factor V Leiden mutation (guanıne-adenine replacement at nucleotide position 1691) was performed as described previously (20)

Statistics We performed two main comparisons by Mann-Whitney-U-test first between women using oral contraceptives and non-users This analysis was performed among cases and controls Secondly, to identify women particularly sensitive to the effect of oral contraceptives, we investigated which ef fects were most striking in patients, as compared with controls, $1 \mathrm{e}$ a comparı son of the magnitude of the change in the former thrombosis patients, vs the change in the control Since our study was in part hypothesis generating, we report significant as well as non significant results

\section{Results}

Given the complexity of the analysis a time frame is given in Fig 1 This figure describes the events which divided the women in different subgroups Of 149 deep-vein thrombosis patients, 104 had used oral contraceptives at the time of the event, which was discontinued in 69 , $1 \mathrm{e}, 30$ still used it at the time of the venepuncture (data on 5 women missing) Of the 169 control women, 54 used oral contraceptives at the time of the venepuncture, and 99 did not (16 missing) This time frame enabled us to verify the effect of oral contraceptives in former thrombosis patients whose thrombosis had happened durnng oral contraceptive use [group $A(n=30)$ vs $B(n=69)$ ] and in control subjects [group C $(\mathrm{n}=54)$ vs $\mathrm{D}(\mathrm{n}=99)]$

We made several comparısons (Table 1) Firstly, we checked the effect of oral contraceptives on hemostatic variables in healthy women by comparing the values of the different hemostatic variables in the control subjects who used oral contraceptives at the time of venepuncture $(n=54)$ with the values in the subjects of the control group who were non-users at the time of blood collection $(n=99)$, 1 e group $C$ vs group D Of the pro-coagulant variables all, except the APTT (lower), were higher in the oral contraceptive-user group For the anti-coagulant variables, free protein $S$ was not really different when we compared oral contraceptive users with non-users, protein $\mathrm{C}$ was higher in the

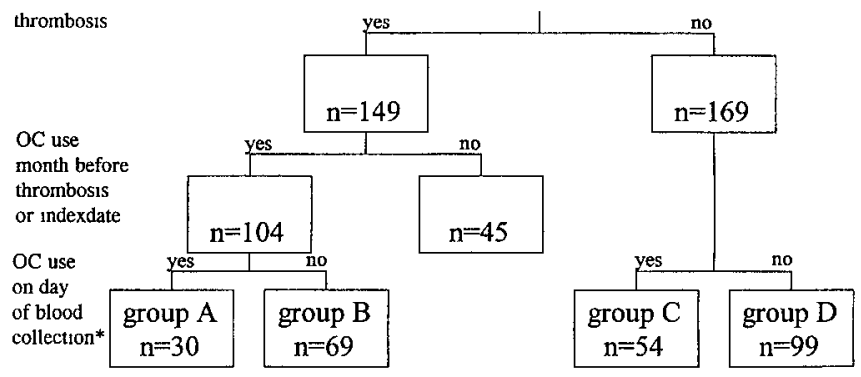

Fig 1 Subgroups of women in the Leiden thrombophilia study Exclusion criterıa women who are above the age of 50 , pregnant, postpartum, menopausal, using injectabté progestagens or anticoagulant treatment $\mathrm{OC}=$ oral contracep tive, ${ }^{*}$ unknown for 21 women 
Table 1 Median values (25th and 75th percentiles) of the hemostatic variables in the different subgroups of the Leiden Thrombophilia Study; i.e. among former thrombosis patients (cases) who developed their thrombosis during oral contraceptive (OC) use and healthy control subjects who continued or discontinued using oral contraceptives

\begin{tabular}{|c|c|c|c|c|c|c|c|}
\hline & $\begin{array}{l}\text { former th } \\
\text { developed } t\end{array}$ & $\begin{array}{l}\text { rombos } \\
\text { heir th } \\
\text { oc }\end{array}$ & $\begin{array}{l}\text { patients who } \\
\text { mbosis during } \\
\end{array}$ & healthy co & itrol su & ibjects & \\
\hline $\begin{array}{l}\text { oral contraceptive use } \\
\text { during blood collection }\end{array}$ & yes & & no & yes & & no & \\
\hline blood test & group A & & group B & group C & & group D & \\
\hline & $n=30$ & & $n=69$ & $n=54$ & & $n=99$ & \\
\hline PRO-COAGULATION & & & & & & & \\
\hline APTT (s.) & $\begin{array}{c}27.2 \\
(25.9-29.0)\end{array}$ & & $\begin{array}{c}27.4 \\
(25.9-28.7)\end{array}$ & $\begin{array}{c}27.7 \\
(26.3-29.1)\end{array}$ & & $\begin{array}{c}28.1 \\
(26.7-29.3)\end{array}$ & \\
\hline Factor VII (U/ml) & $\begin{array}{c}1.28 \\
(1.05-1.42)\end{array}$ & $-*$ & $\begin{array}{c}1.03 \\
(0.90-1.22)\end{array}$ & $\begin{array}{c}1.16 \\
(1.00-1.35)\end{array}$ & ${ }^{*}$ & $\begin{array}{c}1.03 \\
(0.92-1.16)\end{array}$ & \\
\hline Factor VIII $(\mathrm{IU} / \mathrm{ml})$ & $\begin{array}{c}1.43 \\
(1.11-156)\end{array}$ & & $\begin{array}{c}1.37 \\
(1.19-1.61)\end{array}$ & $\begin{array}{c}1.28 \\
(1.00-1.50)\end{array}$ & & $\begin{array}{c}1.12 \\
(0.99-1.35)\end{array}$ & $B \sim * D$ \\
\hline Factor XII (U/ml) & $\begin{array}{c}1.40 \\
(1.12-1.55)\end{array}$ & $-*$ & $\begin{array}{c}1.05 \\
(0.85-1.20)\end{array}$ & $\begin{array}{c}1.35 \\
(1.03+1.52)\end{array}$ & $\rightarrow *$ & $\begin{array}{c}1.00 \\
(0.81-1.18)\end{array}$ & \\
\hline Fibrinogen $(g / L)$ & $(2.8 \cdot 4.0)$ & & $(2.8 .2-3.5)$ & $(3.0-3.7)$ & $\infty$ & $(2.7 .3 .6)$ & \\
\hline Prothrombin (U/ml) & $\begin{array}{c}1.06 \\
(1.00-1.16)\end{array}$ & & $\begin{array}{c}1.03 \\
(0.94-1.16)\end{array}$ & $\begin{array}{c}106 \\
(099-1.16)\end{array}$ & $-*$ & $\left(\begin{array}{c}1.02 \\
(0.93-111)\end{array}\right.$ & \\
\hline ANTI-COAGULATION & & & & & & & \\
\hline Antithrombin (U/mL)" & $\begin{array}{c}091 \\
(0.83-1.06)\end{array}$ & $\rightarrow *$ & $\begin{array}{c}1.00 \\
(0.96-1.06)\end{array}$ & $\begin{array}{c}0.94 \\
(088-1.03)\end{array}$ & $-*$ & $\begin{array}{c}1.00 \\
(0.94-1.07)\end{array}$ & \\
\hline $\mathrm{n}-\mathrm{APC}-\mathrm{sr} \dagger$ & $\begin{array}{c}0.90 \\
(0.80-096)\end{array}$ & $-*$ & $\begin{array}{c}0.95 \\
(0.89-1.00)\end{array}$ & $\begin{array}{c}0.94 \\
(0.90-0.98)\end{array}$ & $-*$ & $\begin{array}{c}1.02 \\
(0.95-1.08)\end{array}$ & $\begin{array}{l}A-* C \\
B=* D\end{array}$ \\
\hline Proten $\mathrm{C}(\mathrm{U} / \mathrm{mL}) \neq$ & $\begin{array}{c}114 \\
(0.95-1.36)\end{array}$ & 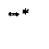 & $\begin{array}{c}1.00 \\
(0.86-1.15)\end{array}$ & $\begin{array}{c}1.05 \\
(0.94-1.17)\end{array}$ & $\rightarrow$ & $\begin{array}{c}0.96 \\
(0.88-1.08)\end{array}$ & \\
\hline Proten $\mathrm{S}(\mathrm{U} / \mathrm{mL})$ & $\begin{array}{c}0.90 \\
(0.78-0.98)\end{array}$ & $-*$ & $\begin{array}{c}1.02 \\
(0.90-1.13)\end{array}$ & $\begin{array}{c}0.84 \\
(0.75-0.93)\end{array}$ & $\stackrel{-*}{*}^{*}$ & $\begin{array}{c}0.96 \\
(0.83-1.09)\end{array}$ & $\mathrm{B} \sim *_{\mathrm{D}}$ \\
\hline Free Protein $\mathrm{S}(\mathrm{U} / \mathrm{mL}) \S \S$ & $\begin{array}{c}0.85 \\
(0.68-096)\end{array}$ & & $\begin{array}{c}0.91 \\
(0.80-1.02)\end{array}$ & $\begin{array}{c}0.88 \\
(0.75-0.96)\end{array}$ & & $\begin{array}{c}0.86 \\
(0.76-1.01)\end{array}$ & \\
\hline 6 to 48 months aft & ter their thromb & asisdat & or the patients or & ndexdate for $\mathrm{cc}$ & itrols. & & \\
\hline significantly differ & $\operatorname{rent}(p<0.05)$ & Man & Whtney-U-test. & & & & \\
\hline Antithrombin, $n=$ & $=29,69,54,99$ & respect & & & & & \\
\hline$n-A P C-s r, n=22$, & $54,53,93$ resp & ectivel & & & & & \\
\hline Protein $\mathrm{C}, \mathrm{n}=30$ & $, 65,54,98$ res & pective & & & & & \\
\hline Proten $S, n=29$, & $68,49,98$ rest & eectivel & & & & & \\
\hline Frec Proten $S, n=$ & $=29,68,46,93$ & respec & & & & & \\
\hline
\end{tabular}

oral contraceptive-user group and the other variables were lower in the oral contraceptive-user group.

Secondly, we investigated the effect of oral contraceptive use in former thrombosis patients, who developed venous thrombosis during oral contraceptive use, by comparing the values of the different hemostatic variables in the former thrombosis patients who still used oral contraceptives at the time of venepuncture $(n=30)$ with the values in the group of former thrombosis patients who were non-users at the time of blood collection $(n=69)$, i.e. group A vs. group B. Again, of the procoagulant variables all, except the APTT (lower), were higher in the oral contraceptive-user group. Of the anticoagulant variables all median values, except for protein $C$ (higher), were lower in the oral contraceptive using group.

Thirdly, we compared effects of oral contraceptives between women who had experienced a venous thrombosis during oral contraceptive use and healthy women. For this comparison we compared the median values of the hemostatic variables among former thrombosis patients (cases) who developed their thrombosis during oral contraceptive use and still used oral contraceptives $(n=30$ ) vs. healthy control subjects who also used oral contraceptives at the time of blood collection $(n=54)$, i.e. group A vs. group C. The former thrombosis patients group showed higher median levels of all pro-coagulant, except the APTT (lower) and prothrombin (no difference), variables. The anticoagulant variables antithrombin, n-APC-sr and free protein $S$ had lower levels in the former thrombosis patients and protein $\mathrm{C}$ and $\mathrm{S}$ were higher.

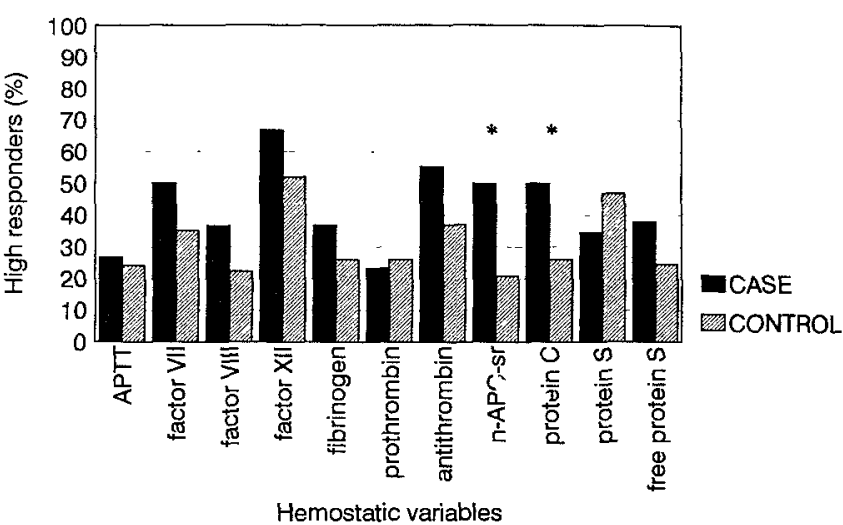

Fig. 2 Percentage of high responders in former thrombosis patients who developed their thrombosis during oral contraceptive $(O C)$ use and continued using OCs (group A) and percentage of high responders in healthy control subjects who were also using OCs at time of blood collection (group C). * Significantly different $(\mathrm{p}<0.05)$ by Chi-Square test.

Another way to compare these effects is shown in Fig. 2. This figure shows the percentage of high responders in former thrombosis patients who developed their thrombosis during oral contraceptive use ( $n=30$, group A) and in healthy control subjects ( $n=54$, group $C)$ who contin ued using oral contraceptives, i.e. women with values above the 75 th percentile or below the 25 th percentile (depending how the variable evolves when oral contraceptives are used). The percentiles were calculated on the group women who consisted of 149 former thrombosis patients and 169 control subjects. The purpose of this table is to identify possible high responders in this "pseudo randomized re-challenge study". For almost all hemostatic variables there were more high responders in the group of former thrombosis patients.

Fourthly, we compared the changes in hemostatic variables induced by oral contraceptives among former thrombosis patients (group A-B) with the differences induced by oral contraceptives among healthy women (group C-D), to see if women who developed venous thrombosis during oral contraceptive use react differently when using oral contraceptives in comparison with healthy women who use oral contraceptives. The changes were greater in the former thrombosis patients group for the procoagulant variables factor VII and for the anti-coagulant variables antithrombin and protein $\mathrm{C}$. For the pro-coagulant variables APTT, factor VIII and for the anti-coagulant variable n-APC-sr the changes were greater in the control women.

Fifthly, to make sure that the effect in the former thrombosis patients group and still using oral contraceptives is really the effect of oral contraceptive use and not a post thrombotic state, we looked at baseline values of control women who did not use oral contraceptives $(n=99)$ and compared these values with the values of former thrombosis patients who discontinued using oral contraceptives $(n=69)$, i.e. group $D$ vs. group B. Most pro-coagulant variables were higher in the former thrombosis patient group, except for the APTT and factor VII. For the anti-coagulant variables, protein $C$, protein $S$ and free protein $S$ the median values were higher in the former thrombosis patients, the levels of antithrombin were almost the same in both groups and n-APC-sr levels were lower in the former thrombosis group.

Sixthly, we counted the total number of variables for which a woman was a high responder, for example when she was a high responder for n-APC-sr and for factor VIII her total number would be 2 . The median (SD) were: for the group former thrombosis patients who developed their thrombosis during oral contraceptive use and who continued using oral contraceptives ( $\mathrm{n}=30$, group $A) ; 5(2.0)$, for the group for- 
mer thrombosis patients who developed their thrombosis during oral contraceptive use and who discontinued using oral contraceptives $(\mathrm{n}=69$, group $\mathrm{C}) ; 3(1.6)$, for the group healthy women who used oral contraceptives at the time of venepuncture $(n=54) ; 3(1.7)$ and for the group healthy control women who were not using oral contraceptives at the time of venepuncture $(n=99) ; 2(1.3)$. When comparing the groups, the differences in group A vs. the group $B$, group $C$ vs. group D, the group $A$ vs. group $C$ and group $B$ vs. group $D$ were significant.

\section{Discussion}

In this pseudo-randomised study on the effect of challenging the hemostatic system by oral contraceptives in former thrombosis patients (during oral contraceptive use), we found that the hemostatic system of former thrombosis patients has a more pronounced reaction to oral contraceptives (especially for factor VII, antithrombin, n-APC-sr and protein $\mathrm{C}$ ) in comparison to healthy control subjects.

The effects of oral contraceptive use among healthy control subjects (Table 1) are generally in agreement with the findings of many randomised studies of different types of oral contraceptives (containing different types and doses of estrogen and progestogen) and their effects on hemostasis in healthy volunteers (13-16). Moreover this general trend of oral contraceptive effect was the same among former thrombosis patients. Only for free protein $S$ levels we did not observe reduced levels associated with use of oral contraceptives as has been described by others (34-36).

The comparisons in our study also show that a woman who has experienced a deep-vein thrombosis, even if she is not currently using oral contraceptives, still shows characteristics of changes in the hemostatic system that are similar as if sex steroids are involved (like in pregnant women and in women using oral contraceptives) $(15,37)$, i.e. her hemostatic system is in a more hyper coagulant or prothrombotic state.

A problem in our study is that we had no base-line values, so it is possible that some differences were due to the post thrombotic state. However, the time elapsed from the event to the time of blood collection was more than six months in all thrombosis patients. During these six months the values of the hemostatic variables affected by the thrombosis event are likely to have returned to the values as present before the event.

When we compare the median values of the hemostatic variables among former thrombosis patients (cases) and healthy control subjects irrespective of their oral contraceptive status, we see some of the established risk factors for venous thrombosis, such as high levels of factor VIII (31), high levels of fibrinogen (30), low levels of antithrombin (29) and low levels of n-APC-sr (28). Some effects are not related to thrombosis risk, i.e., high levels of protein C (38), factor VII (30) and factor XII (32).

While for total protein $\mathrm{S}$ we found a significant decrease, we did not find a decrease of free protein $S$ with oral contraceptive use that one usually expects. Several studies have shown decreases during oral contraceptive use, for both total and free protein $S$ levels (34-30, 39-42). There is an important difference in design between the studies, however: most previously reported studies followed new-users for a relatively short period of time, i.e. 6 to 12 months, while our study was a cross-section of women, i.e., mainly long term users. A transient effect would therefore had been apparent in the earlier studies, but less so in our study. Several reports showed a marked effect during the first months of oral contraceptive use and a decline of that effect with prolonged use $(34,35,39,42)$.

In a next comparison it is remarkable that the difference in the effect on hemostasis of oral contraceptives is more marked in women who developed deep-vein thrombosis during oral contraceptive use than in control subjects. There was a greater difference in former thrombosis patients for the following hemostatic variables: pro-coagulation: factor VII and anti-coagulation: antithrombin, protein C. Apparently the hemostatic system of a former thrombosis patient, still using oral contraceptives, reacts different from a healthy control subject when using oral contraceptives. Our data suggest that some women who will suffer a thrombotic event show more pronounced effects of oral contraceptives. This may point to some women being more vulnerable to the thrombogenic effects of oral contraceptives.

Considering the various analyses, most striking are the differences in the median values of factor VII, antithrombin, n-APC-sr. Especially for these hemostatic variables it seems likely that women who developed deep-vein thrombosis during oral contraceptive use in the past, do respond differently to oral contraceptive use than their control subjects.

As was recently described by others (43-47), we found an effect on sensitivity to APC when women use oral contraceptives, also among women who did not carry the factor V Leiden mutation. This acquired $\mathrm{APC}$-resistance is likely to be relevant in the pathogenesis of venous thrombosis.

At this moment the types of progestogen used in oral contraceptives are of special interest, since reports were published on the difference in risk of venous thrombosis with the different types of progestogens used in oral contraceptives (6-10). Although both second and third generation oral contraceptives were used by a substantial number of the women in our study, the numbers in subgroups became too small to make meaningfuif comparisons between types of oral contraceptives possible (data not shown).

The differences in hemostatic variables in this study are between individuals, not within individuals, information of the base line values is lacking. On the other hand this study mimics the reality of the randomised trial sufficiently to infer that in some women the hemostatic system reacts more pronounced to oral contraceptives than in other women. The less likely alternative is that individuals who have had a previous thromboembolic event only become "high hemostatic responders" afterwards, when exposed to another risk factor for venous thromboembolism, i.e. oral contraceptives.

In this pseudo-randomised study some women were still using oral contraceptives after a thrombotic event (former thrombosis patients), while others were barred from using oral contraceptives. Mostly it was the physician who treated the patient, who had influenced this decision. The only influence on this decision could be the extensiveness of the deep venous thrombosis and possibly the combination with pulmonary embolus.

The data derived from the different analysis in our study may help to explain why women who use oral contraceptives, and have no other known risk factors (such as inherited clotting defects, malignancy), develop thrombosis. Apparently some women become "high hemostatic responders" when exposed to oral contraceptives, and these may be the women most vulnerable to its thrombogenic effects.

\section{Acknowledgements}

We thank all the patients who took part in this study, Dr. F. J. M. van der Meer (Anticoagulation Clinic Leiden), Dr. L. P. Colly (Anticoagulation Clinic Amsterdam) and Dr. P. H. Trienekens (Anticoagulation Clinic Rotterdam) for their cooperation; Mrs. A. yan Beek for secretarial and administrative support; Mrs. T. Visser for laboratory assistance; and Mr. P. A. van der Velden for DNA analysis. The study was funded by the Netherlands Heart Foundation (number 89 063). 


\section{References}

1. Jordan WM. Pulmonary embolism. Lancet 1961; 2: 1146-7

2. Inman WHW, Vessey MP, Westerholm B, Engelund A. Thromboembolic disease and the steroidal content of oral contraceptives a report to the committee on safety of drugs. British Medical Journal 1970; 2: 203-9.

3. Meade TW. Risks and mechanism of cardiovascular events in users of oral contraceptives. Am J Obstet Gynecol 1988; 158: 1646-52.

4. Gerstman BB, Piper JM, Tomita DK, Frerguson WJ, Stadel BV, Lundin FE. Oral contraceptive estrogen dose and the risk of deep venous thromboembolic disease. American Journal of Epidemiology 1991; 133: 32-7.

5. Bloemenkamp KWM, Rosendaal FR, Helmerhorst FM, Vandenbroucke JP. Evidence that currently available pills are associated with cardiovascular disease: venous disease. In: Hannaford PC, Webb AMC. Evidence-guided Piescribing of the Pill 1996: 61-76 (Carnforth, UK: Parthenon Publishing).

6. World Health Organization Collaborative Study of Cardiovascular Disease and Steroid Hormone Contraception. Venous thromboembolic disease and combined oral contraceptives: Results of international multicentre casecontrol study. Lancet 1995; 346: 1575-82.

7. Vorld Health Organization Collaborative Study of Cardiovascular Disease and Steroid Hormone Contraception. Effect of different progestagens in low oestrogen oral contraceptives on venous thromboembolic disease. Lancet 1995; 346: 1582-8.

8. Jick H, Jick SS, Gurewich V, Myers MW, Vasilakis C. Risk of idiopathic cardiovascular death and nonfatal venous thromboembolism in women using oral contraceptives with differing progestagen components. Lancet 1995; 346: 1589-93.

9. Bloemenkamp KWM, Rosendaal FR, Helmerhorst FM, Buller HR, Vandenbroucke JP. Enhancement by factor V Leiden mutation of risk of deepvein thrombosis associated with oral contraceptives containing third-generation progestagen. Lancet 1995; 346: 1593-6.

10. Spitzer WO, Lewis MA, Heinemann LAJ, Thorogood M, MacRae KD on behalf of Transnational Research Group on Oral Contraceptives and the Health of Young women. Third generation oral contraceptives and risk of venous thromboembolic disorders: an international case-control study. BMJ 1996; 312: 83-8.

11. Thomas DP. Pathogenesis of venous thrombosis. In: Haemostasis and Thrombosis, 3rd edition. Bloom AL, Forbes CD, Thomas DP, Tuddenham EGD (eds). New York: Churchill-Livingstone 1994; pp. 1335-47.

12. Goldhaber SZ. Epidemiology of pulmonary embolism and deep venous thrombosis. In: Haemostasis and Thrombosis. 3rd edition. Bloom AL, Forbes CD, Thomas DP, Tuddenham EGD (eds). New York: ChurchillLivingstone 1994; pp. 1327-33.

13. Fotherby K, Caldwell ADS. New progestogens in oral contraception. Contraception 1994; 49: 1-32.

14. Robinson GE. Low-dose combined oral contraceptives. British J Obstet and Gynaecol 1994; 101: 1036-42.

15. Beller FK, Ebert C. Effects of oral contraceptives on blood coagulation. A review. Obstetrical and Gynecological Survey 1985; 40: 425-36.

16. Kluft C, Lansink M. Effect of oral contraceptives on haemostasis variables. Thromb Haemost 1997; 78: 315-26.

17. Mammen EF. Oral contraceptives and blood coagulation: a critical review. Am J Obstet Gynecol 1982; 142: 781-90.

18. Meade TW. Oral contraceptives, clotting factors, and thrombosis. Am J Obstet Gynecol 1982; 142: 758-61.

19. Wessler S. Estrogen-associated thromboembolism. Ann Epidemiol 1992; 2: 439-43.

20. Bertina RM, Koeleman RPC, Koster T, Rosendaal FR, Dirven RJ, de Ronde $\mathrm{H}$, van der Velden PA, Reitsma PH. Mutation in blood coagulation factor $\mathrm{V}$ associated with resistance to activated protein C. Nature 1994; 369: 64-7.

21. Rosendaal FR, Koster T, Vandenbroucke JP, Reitsma PH. High risk of thrombosis in patients homozygous for factor $\mathrm{V}$ Leiden (activated protein $\mathrm{C}$ resistance) [see comments]. Blood 1995; 85: 1504-8.

22. Vandenbroucke JP, Koster T, Briët E, Reitsma PH, Bertina RM, Rosendaal FR. Inceased risk of venous thrombosis in oral-contraceptive users who are carriers of factor V Leiden mutation. Lancet 1994; 334: 1453-7.
23. Bick RL, Pegram M. Syndromes of hypercoagulability and Thrombosis: a review. Seminars in Thrombosis and Hemostasis 1994; 20 (1): 109-32.

24. Girolami A, Simioni P, Girolami B, Zanardi S. The role of drugs, paticularly oral contraceptives, in triggering thrombosis in congenital defects of coagulation inhibitors: a study of six patients. Blood Coagulation and Fibrinolysis 1991; 2: 673-8.

25. Girolami A, Simioni P, Sartori MT, Zanardi S. Oral contraceptives caused thrombosis in a monoovular twin with protein $\mathrm{C}$ deficiency, while the other, without medication, remained asymptomatic [letter]. Blood Coagul Fibrinolysis 1992; 3: 119-20.

26. Pabinger I, Schneider B. Thrombotic risk of women with hereditary antithrombin III-, protein $\mathrm{C}$ - and protein S-deficiency taking oral contraceptive medication. The GTH Study Group on Natural Inhibitors. Thromb Haemost 1994; 71: 548-52.

27. Alving BM, Comp PC. Recent advances in understanding clotting and evaluating patients with recurrent thrombosis. Am J Obstet Gynecol 1992; 167; 1184-91.

28. Koster T, Rosendaal FR, de Ronde H, Briët E, Vandenbroucke JP, Bertina RM. Venous thrombosis due to poor anticoagulant response to activated protein C: Leiden Thrombophilia Study. Lancet 1993; 342: 1503-6.

29. Koster T, Rosendaal FR, Briët E, Van der Meer FJM, Colly LP, Trienekens PH, Poort SR, Vandenbroucke JP. Protein C deficiency in a controlled series of unselected outpatients: an infrequent but clear risk factor for venous thrombosis (Leiden Thrombophilia Study). Blood 1995; 85: 2756-61.

30. Koster T, Rosendaal FR, Reitsma PH, Van der Velden PA, Briët E, Vandenbroucke JP. Factor VII and fibrinogen levels as risk factors for venous thrombosis. A case-control study of plasma levels and DNA polymorphisms, Leiden thrombophilia Study. Thromb Haemost 1994; 71: 719-22.

31. Koster T, Blann AD, Briët E, Vandenbroucke JP, Rosendaal FR. Role of clotting factor VIII in effect of von Willebrand factor on occurrence of deep-vein thrombosis. Lancet 1995; 345: 152-5.

32. Koster T, Rosendaal FR, Briët E, Vandenbroucke JP. John Hageman's factor and deep-vein thrombosis: Leiden thrombophilia Study. Br J Haematol 1994; 87: 422-4.

33. De Ronde H, Bertina RM. Laboratory diagnosis of APC-resistance: a critical evaluation of the test and the devlopment of diagnostic criteria. Thromb Haemost 1994; 72: 880-6.

34. Quehenberger P, Loner U, Kapiotis S, Handler S, Schneider B, Huber J, Speiser W. Increased levels of activated factor VII and decreased plasma protein $\mathrm{S}$ activity and circulating thrombomodulin during use of oral contraceptives. Thromb Haemost 1996; 76 (5): 729-34.

35. Basdevant A, Conard J, Pelissier C, Guyene TT, Lapousterle C, Mayer M, Gran BG, Degrelle H. Hemostatic and metabolic effects of lowering the ethinyl-estradiol dose from $30 \mu \mathrm{g}$ to $20 \mu \mathrm{g}$ in oral contraceptives containing desogestrel. Contraception 1993; 48: 193-204.

36. Melissari E, Kakkar VV. The effects of oestrogenadministration on the plasma free protein $S$ and C4-b-binding protein. Thromb Res 1988; 49 : 489-95.

37. Beller FK, Ebert CH. The coagulation and fibrinolytic system in pregnancy and in the puerperium. Eur J Obstet Gynecol Reprod Biol 1982; 13: 177-97.

38. Allaart CF, Poort SR, Rosendaal FR, Reitsma PH, Bertina RM, Briët E. Increased risk of venous thrombosis in carriers of hereditary protein $C$ deficiency defect. Lancet 1993; 341: 134-8.

39. Winkler UH, Schindler AE, Endrikat J, Dusterberg B. A comparative study of the effects of the hemostatic system of two monophasic gestodene oral contraceptives containing $20 \mu \mathrm{g}$ and $30 \mu \mathrm{g}$ ethinylestradiol. Contraception 1996; 53: 75-84.

40. Petersen KR, Sidelmann J, Skouby SO, Jespersen J. Effects of monophasic low-dose oral contraceptives on fibrin formation and resolution in young women. Am J Obstet Gynecol 1993; 168: 32-8.

41. Jespersen J, Petersen KR, Skouby SO. Effects of newer oral contraceptives on the inhibition of coagulation and fibrinolysis in relation to dosage and type of steroid. Am J Obstet Gynecol 1990; 163: 396-403.

42. Cachrimanidou A-C, Hellberg D, Nilsson S, von Schoulz B, Crona N, Siegbahn A. Hemostasis profile and lipid metabolism with long-interval use 
of a desogestrel-containing oral contraceptive. Contraception 1994; 50: 153-65.

43. Henkens CMA, Bom VJJ, Seinen AJ, Meer van der J. Sensitivity to activated protein $\mathrm{C}$; Influence of oral contraceptoives and sex. Thromb Haemost 1995; 73 (3): 402-4.

44. Østerud B, Robertsen R, Åsvang GB, Thijssen F. Resistance to activated protein $C$ is reduced in women using oral contraceptives. Blood Coagul and Fibrinolysis 1994; 5: 853-4

45. Olivieri O, Friso S, Manzato F, Guella A, Bernardi F, Lunghi B, et al. Resistance to activated protein $C$ in healthy women taking oral contraceptives. Br J Haematol 1995; 91: 465-70.
46. Bokarewa MI, Falk G, Sten-Linder M, Egberg N, Blomback M, Bremme K. Thrombotic risk factors and oral contraception. J Lab Clin Med 1995; 126: 294-8.

47. Rosing J, Tans G, Nicolaes GAF, et al. Oral contraceptives and venous thrombosis; different sensitivities to activated protein $\mathrm{C}$ in women using second- and third generation oral contraceptives. Br J Haematol 1997; 97: 233-38.

Received July 7, 1997 Accepted after resubmission May 13, 1998

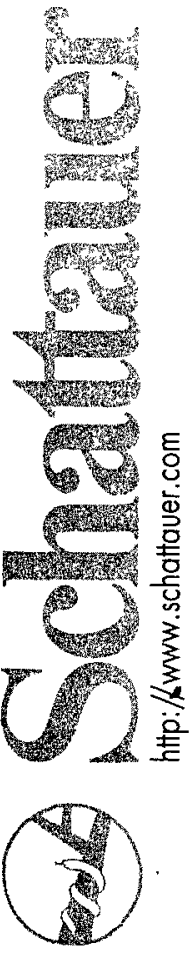

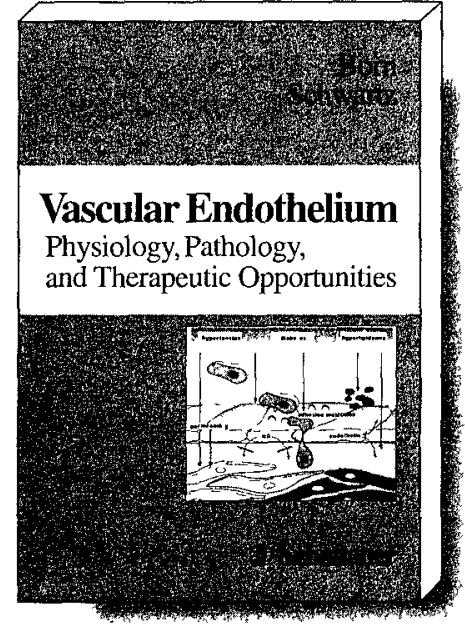

Born/Schwartz (eds.)

Vascular Endothelium

Physiology, Pathology, and Therapeutic Opportunities

1997. 413 pages, 123 illustrations, 9 tables, paperback

DM 98.00 /approx. US $\$ 70.00$

ISBN 3.7945-1762.8
Recent discoveries have established the endothelium as a very large and highly active endocrine organ which, through its strategic situation between the blood and the rest of the body, is responsible for a host of vital physiological functions. This in turn is leading to rapid advances in understanding the pathogenesis of some of the most serious and most common diseases, including hypertension, atherosclerosis, and inflammation. Editors and authors are internationally leading scientists in these investigations.

For the endothelium, as for all other tissues, morphological techniques, however ingeniously applied, can provide no more than successive snapshots of continuous dynamic processes. It is only in more recent years that these techniques have been supplemented by cell culture in vitro and by ingenious uses of endothelial mediators in vivo. Nevertheless, many of the most important questions about endothelial functions remain to be answered. It is the purpose of this book to indicate directions along which answers may be found.

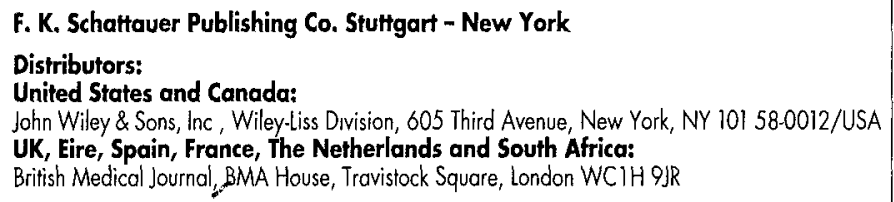

